\title{
A possible solution for flood risk mitigation in Ho Chi Minh City and the lower Sai Gon-Dong Nai River Basin
}

\author{
Cong San Dinh ${ }^{1, *}$, Binh Duong Nguyen ${ }^{1}$, Kim Dan Nguyen ${ }^{2}$ and Van-Thanh-Van Nguyen ${ }^{3}$ \\ ${ }^{1}$ Southern Institute of Water Resources Research, Ho Chi Minh City, Vietnam \\ ${ }^{2}$ Université Paris-Est, Laboratoire d'Hydraulique Saint-Venant (LHSV), Chatou, France \\ ${ }^{3}$ Department of Civil Engineering and Applied Mechanics, McGill University, Montréal, Canada
}

Received: 1 October 2018 / Accepted: 2 August 2019

\begin{abstract}
The Sai Gon-Dong Nai Basin plays a very important role in the socio-economic development of Vietnam. The area of Ho Chi Minh (HCM) City is about $2095 \mathrm{~km}^{2}, 60 \%$ of which lying under $2 \mathrm{~m}$ above MSL. Its population is about 8.136 million. Economic development has led to flood-related problems. The causes of floods are monsoon rainfalls, high tides, and outflows from the Dau Tieng Reservoir, upstream of HCM City. This paper proposed a plausible solution for flood mitigation in HCM City by uplifting the Dau Tieng dam crest. This solution can be recommended based on the results of an extensive simulation study which used: (i) a statistical downscaling procedure for evaluating the climate change (CC) impacts on precipitations; (ii) the MARINE model for simulating the rainfall-runoff process; (iii) the Telemac2D model for simulating the inundation; and (iv) the GIS tool for representing the inundated areas under different CC scenarios. It was found that under the A2 scenario an increase of rainfall by $2050 \mathrm{~s}$ and added $40 \%$ of this rainfall (assuming due to tropical depression), the maximum regulated discharges released from the Dau Tieng dam could reach 1650,500 and $300 \mathrm{~m}^{3} \mathrm{~s}^{-1}$ without any enhancement then with the dam enhancement of 1.0 and $1.5 \mathrm{~m}$, respectively. As comparing to event occurred on July 21, 2009 due to the combined effect of a heavy rainfall and a high tide condition, the inner city flooding area increases by $1.2,1.3$ and $8.2 \%$ with the dam enhancement of 1.5, $1.0 \mathrm{~m}$ and without dam enhancement, respectively. Results of this study have therefore provided critical information for making a logical decision concerning the possibility of uplifting the height of the crest of the Dau Tieng dam to mitigate the urban flooding in HCM City under the threat of $\mathrm{CC}$ and sea level rise.
\end{abstract}

Keywords: flood mitigation / climate change / hydrologic modelling / Sai Gon-Dong Nai Basin / Dau Tieng dam enhancement

Résumé - Une possible solution pour la réduction du risque d'inondation dans la ville de Ho Chi Minh et dans la partie avale du Bassin de Sai Gon-Dong Nai. Le bassin de Sai Gon-Dong Nai joue un rôle très important dans le développement socio-économique du Vietnam. La superficie de la ville de Ho Chi Minh (HCM) est d'environ $2095 \mathrm{~km}^{2}$, dont $60 \%$ située à moins de $2 \mathrm{~m}$ au-dessus du niveau moyen de la mer (MSL). Sa population est d'environ 8,136 millions. Le développement économique a conduit à des problèmes aigus liés aux inondations. Les causes des inondations sont les pluies de mousson, les marées de forts coefficients et le déversement des crues du réservoir de Dau Tieng, en amont de Ho Chi Minh (HCM) Ville. Cet article présente une solution envisageable pour atténuer les inondations dans la ville d'HCM par l'augmentation du niveau du barrage de Dau Tieng. L'étude a utilisé : (i) la SDSM pour considérer l'impact du changement climatique; (ii) le modèle pluie-débit MARINE pour simuler le ruissellement; (iii) Telemac2D pour simuler l'inondation; et (iv) un outil SIG pour représenter les différents scénarios d'inondation. Les résultats montrent que, pour le scénario A2 prenant en compte une augmentation de $40 \%$ des précipitations en période de mousson d'ici à 2050, les débits maximaux déchargés par le réservoir Dau Tieng vers l'aval sont respectivement de 1650,500 et $300 \mathrm{~m}^{3} \mathrm{~s}^{-1}$ sans rehausse de la crête du barrage, puis avec rehausse de 1,0 ou 1,5 m. En comparant aux niveaux atteints lors de la sévère inondation du 21/7/2009, causée par fortes pluies combinées avec une forte marée, la surface inondée dans le centre-ville

\footnotetext{
*Correspondence: dinhcongsan61@gmail.com
} 
(arrondissements 1 à 12) augmenterait selon ce scénario A2 de 1,2\% pour une rehausse de 1,5 m ou $1,3 \%$ pour une rehausse de 1,0 m. La surface inondée seraient quant à elle supérieure de 8,2\% si l'on conservait le niveau actuel du barrage. Cette étude a donc fourni des résultats primordiaux pour la prise de décision concernant l'élévation ou non du barrage de Dau Tieng afin de réduire dans le futur le risque lié aux inondations dues au changement climatique dans Ho Chi Minh Ville.

Mots clés : mitigation de crues / changement climatique / modélisation hydrologique / Bassin de Sai Gon-Dong Nai / surélévation de la crête du barrage de Dau Tieng

\section{Introduction}

Urban flooding is often caused by heavy rainfall, overbank flows from rivers, high tides and/or storm surges (Tingsanchali, 2012; Cheng et al., 2017; Verwey et al., 2017). In high and extremely high-water years, an appropriate urban water management measure is needed to mitigate the flooding problem. In particular, during high water years, the water level in water supply reservoirs must be drawn down before the arrival of heavy rains. This can cause conflicts between different stakeholders with different conflicting water demands in the basin as a whole. Consequently, for the Sai Gon-Dong Nai Basin (SGDNB) in Vietnam, in order to minimize the flood damages in regions located downstream from the Dau Tieng dam during the high-water years, there is always a conflict between the required reduction of outflows that could be released from the reservoir to downstream, and the water amount that is needed to be kept in the reservoir for other water uses.

In Vietnam, the SGDNB is the third largest river basin (after Mekong and Red Rivers), including 11 provinces with an area of $43450 \mathrm{~km}^{2}$, situated in the South East region of Vietnam. The total average annual rainfall is about $2100 \mathrm{~mm}$ and equivalent to 84 billion $\mathrm{m}^{3}$. Total annual average flow at the river mouth (Soai-Rap) is about 37 billion $^{3}$ year $^{-1}$. The SGDNB has strongly contributed to the economic development of the country, accounting for $40 \%$ in GDP and $60 \%$ of state budget. Its population is about 16272 million (2007) with 52 races, $48.5 \%$ of which live in urban areas (2005). At downstream, the SGDNB connects to the East Sea (Pacific Ocean) with diurnal and semidiurnal tides. Tidal amplitude is about $3 \mathrm{~m}$.

The area of Ho Chi Minh (HCM) City is about $2095 \mathrm{~km}^{2}$, $60 \%$ of which is low lying land (under $2.00 \mathrm{~m}$ above MSL). The population is about 8.136 million (in 2015) (see Fig. 1). Almost $100 \%$ of water consumptions in HCM City comes from the Dau Tieng Reservoir. The function of this reservoir, according to the decision of Ministry of Agriculture and Rural Development (No. 137/2000/QĐ-BNN-QLN dated 18/12/ 2000 ) is to supply water to agricultural (of four provinces: Tay Ninh, Binh Duong, Long An and HCM), domestical and industrial users.

Economic development has led to flood-related problems downstream of SGDNB. Origins of flood hazard in HCM City are monsoon rainfalls, high tides (frequent) and over riverbank of flood flows released from the Dau Tieng Reservoir especially in the rainy season and associated with high tides (the impact of flood flows from the Tri An Reservoir is insignificant). Economic damages due to floods become more and more critical. For instance, about 100 clusters in HCM City were inundated 476 times in 2006. In addition, inundation damages due to the flooding event on November 13, 2008 have been estimated in the order of several million \$US just for this particular event. Flood situation will be exacerbated by the potential climate change (CC) impacts in the future.

In this context, the French Development Agency(FDA) had sponsored a research project entitled "Sustainable Flood Risk Management (SFRM) for the Sai Gon-Dong Nai River Basin" in order to address five main objectives: i) to assess the flood risks; ii) to evaluate various existing flood-control measures; iii) to develop different flood management strategies; iv) to improve existing flood resilience procedures; and $\mathrm{v}$ ) to promote public awareness and participation in the SFRM. In addition, the Ministry of Science and Technology ( MOST) had provided a financial support to conduct the research project named "Study and recommendations on measures to improve the water use efficiency and to ensure the safety of the main works downstream of the Dau Tieng Reservoir, due to CC and extreme weather conditions". This project mainly solves the conflicts between the Dau Tieng Reservoir safety and the reduction of urban flooding losses downstream, especially in HCM City, taking into consideration the potential CC impacts. As Verwey et al. (2017) have indicated that flood damage mitigation would be possible if flood peak discharge should be reduced, this study is therefore aiming at evaluating the effects of uplifting the dam crest (which reduces flood discharges) on the reduction of the inundated areas downstream.

\section{Methodology}

Figure 2 illustrates the successive steps, which have been followed in this study.

In order to study the impacts of Climate Change on rainfalls in the study area, the popular Statistical Downscaling Model (SDSM) version 4.2 has been used (Wilby et al., 2002; Wilby and Dawson, 2007). Using this model, the Intensity Duration Frequency (IDF) curves of rainfalls at the Tan Son Hoa meteorological station (located in the urban area) and the downscaling results on rainfall intensities for three stations at Dau Tieng Reservoir have been obtained under different CC scenarios.

In order to simulate the rainfall-runoff process in mountainous areas, a physically based, space-time distributed hydrological model "MARINE" (Model of Anticipation of Runoff and INundation for Extreme events) (Estupina-Borrell et al., 2006) has been used. The main advantage of MARINE is its ability to simulate the runoff process for basins with limited runoff data and it can be used in an operational mode for realtime flood forecasting. The model consists in two components: (i) the first component is a "basin" flood module that generates 


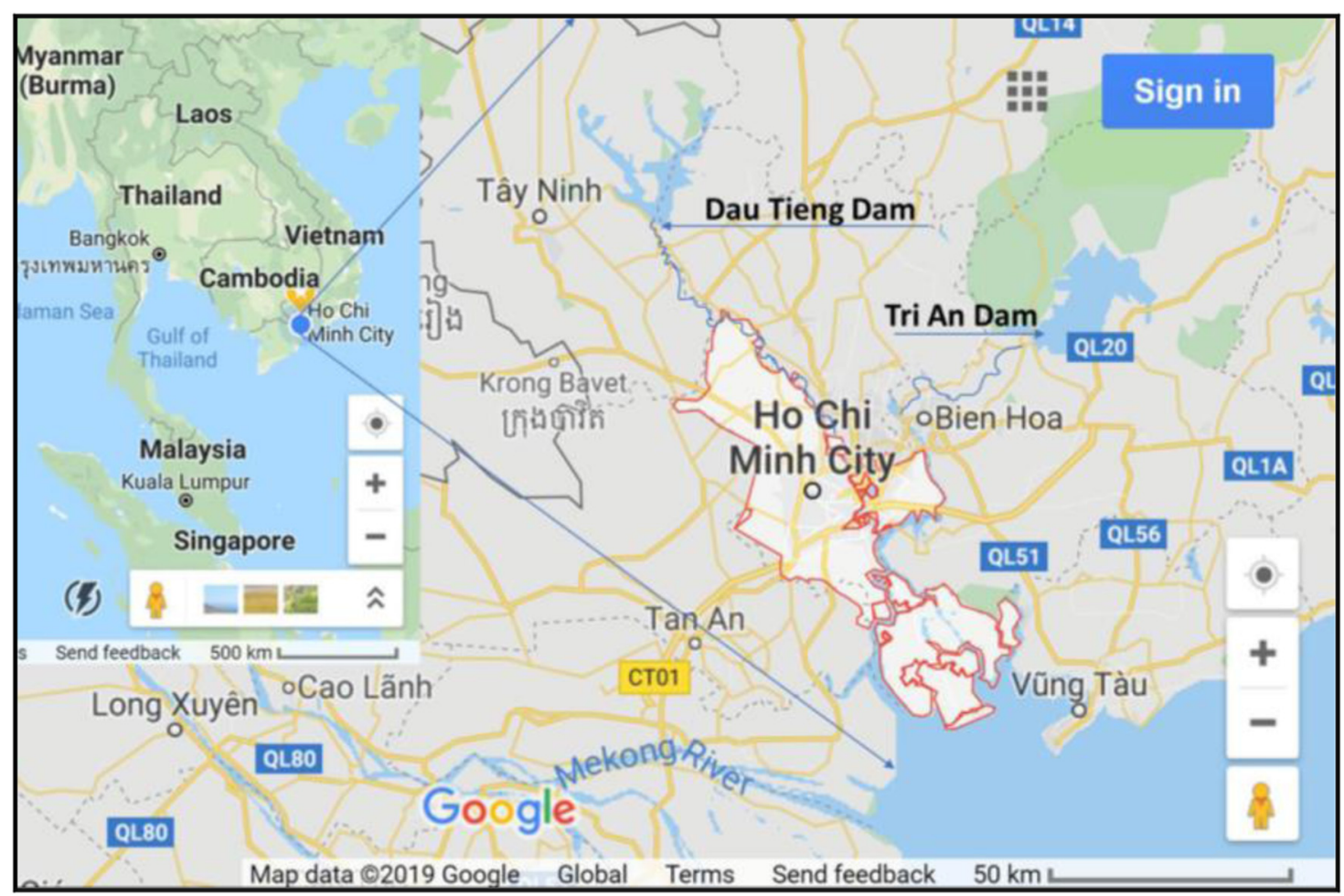

Fig. 1. Ho Chi Minh City in the downstream of Sai Gon-Dong Nai Basin (source: Google Map).

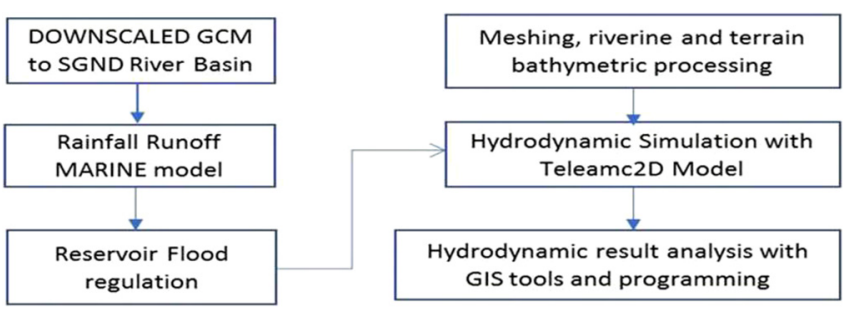

Fig. 2. The study methodologies.

flood runoff in the up-stream part of the watershed, and (ii) the second component is the "stream network" module, which propagates the flood in the main river and its subsidiaries. The stream flood propagation model simulates flood propagation in main rivers by solving the 1D Saint-Venant equations. In assuming that the field is fully saturated, infiltration and underground flows are not taken into account in this model. Flood regulation has been based on the Dau Tieng Reservoir characteristic curves $(\mathrm{V}-\mathrm{Z} ; \mathrm{F}-\mathrm{Z})$ and the basic water balance equation is as follows:

$$
(Q-q) d t=F d Z
$$

where $Q$ is the inflow discharge $\left(\mathrm{m}^{3} \mathrm{~s}^{-1}\right) ; q$ is the flood release discharge $\left(\mathrm{m}^{3} \mathrm{~s}^{-1}\right)$ via spillway; and $F$ is the reservoir area $\left(\mathrm{m}^{2}\right)$ at the water level $Z$.

An open source Telemac2D model (Hervouet, 2006) has been used to simulate floods in downstream of the SGDNB, with the advantage to solve urban flood prevention problems later. In addition, GIS (Geographic Information System) tool was used to map the inundated areas in order to compare the impact of different scenarios. It is noted that the impact of Tri An Reservoir on flooding in HCM City was insignificant (Dinh et al., 2010) due to the fact that this reservoir is connected with the Dong Nai River - a very large river as compared to the Sai Gon River. Therefore, flood discharges coming from Tri An Reservoir are set to be an unchanged value that is averaged over the flood seasons.

\section{Results and discussions}

\subsection{Climate change impacts on precipitation}

There are several meteorological stations in the study area. However, due to the availability of rainfall data, only four stations were selected for the downscaling work: Tan Son Hoa (in HCM City) and Dau Tieng, Loc Ninh, Can Dang (in the upstream area) (see Fig. 7). The rainfall data at Tan Son Hoa station were measured by a recording rain gage with a very high resolution of one-minute interval, while rainfalls at the remaining three stations were measured by non-recording gages at one-day time scale.

\subsubsection{IDF relations at Tan Son Hoa station}

To establish the IDF curves in the context of CC at Tan Son Hoa station, climate simulations from two Global Climate Models (CGCM3 from Canada and HadCM3 from UK) have been used to provide projected rainfalls under different $\mathrm{CC}$ scenarios for future periods 2020s, 2050s and 2080s. The scenarios selected for this study consist of A2 and B2 scenarios for $\mathrm{CGCM} 3$, and $\mathrm{A} 2$ and $\mathrm{A} 1 \mathrm{~B}$ for HadCM3 as proposed by the 

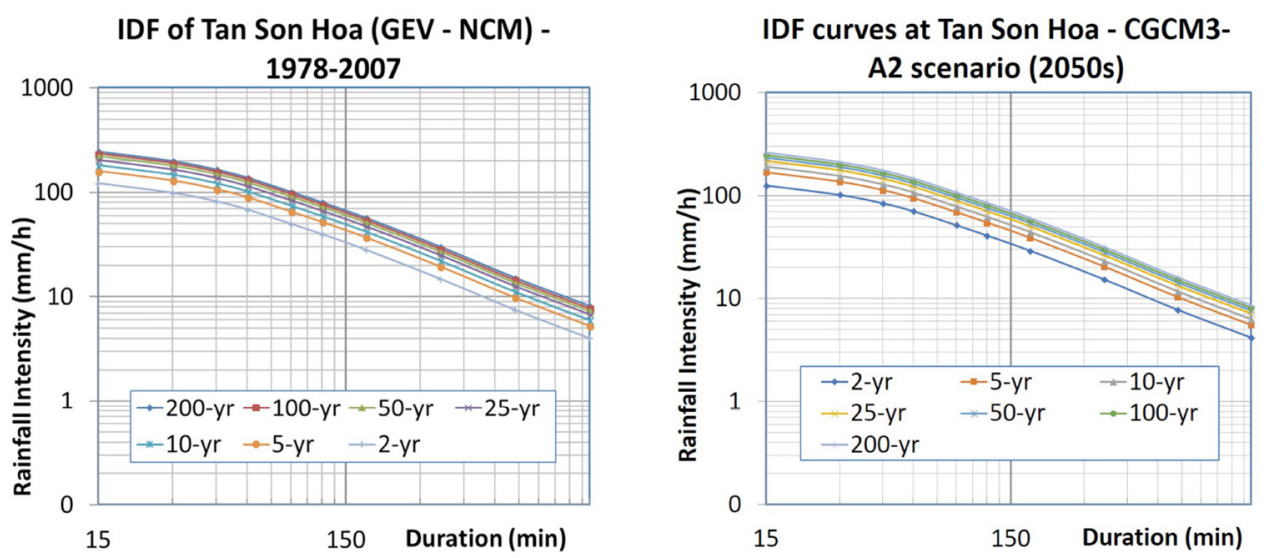

Fig. 3. IDF curves at Tan Son Hoa station for 1978-2007 period (left) and 2050s period for A2 scenario (right).

Table 1. Extreme rainfalls $(\mathrm{mm} / \mathrm{h})$ at Tan Son Hoa station for scenario A2 for 2050s (HadCM3 model).

\begin{tabular}{|c|c|c|c|c|c|c|c|c|c|c|c|}
\hline \multirow[t]{2}{*}{ No. } & \multirow[t]{2}{*}{ Return period (yr.) } & \multicolumn{10}{|c|}{ Minutes } \\
\hline & & 15 & 30 & 45 & 60 & 90 & 120 & 180 & 360 & 720 & 1440 \\
\hline 1 & 200 & 202.74 & 164.14 & 136.02 & 113.73 & 83.12 & 66.02 & 46.97 & 24.76 & 12.52 & 6.71 \\
\hline 2 & 100 & 198.00 & 160.31 & 132.85 & 111.07 & 81.17 & 64.48 & 45.87 & 24.19 & 12.23 & 6.55 \\
\hline 3 & 50 & 192.64 & 155.97 & 129.25 & 108.06 & 78.98 & 62.73 & 44.63 & 23.53 & 11.90 & 6.37 \\
\hline 4 & 25 & 186.53 & 151.02 & 125.15 & 104.64 & 76.47 & 60.74 & 43.22 & 22.79 & 11.52 & 6.17 \\
\hline 5 & 10 & 177.03 & 143.33 & 118.78 & 99.31 & 72.58 & 57.65 & 41.01 & 21.62 & 10.94 & 5.86 \\
\hline 6 & 5 & 168.32 & 136.28 & 112.93 & 94.42 & 69.01 & 54.81 & 39.00 & 20.56 & 10.40 & 5.57 \\
\hline 7 & 2 & 152.80 & 123.72 & 102.52 & 85.72 & 62.65 & 49.76 & 35.40 & 18.67 & 9.44 & 5.05 \\
\hline
\end{tabular}

IPCC (International Panel on Climate Change; see http://www. ipcc.ch/ipccreports/sres/emission/index.php?idp $=98$ for the details of different scenarios). The results obtained from these two GCM models are quite similar. In particular, for scenario A2, the rainfall intensity of two-year return period has increased by $22.1,25.6$ and $34.5 \%$ for $2020 \mathrm{~s}, 2050 \mathrm{~s}$ and 2080s respectively as compared with rainfall intensities in the historical 1978-2007 period; and for scenario B2, the rainfall intensity of two-year return period has increased by $20.1,21.6$ and $29.4 \%$ for $2020 \mathrm{~s}, 2050 \mathrm{~s}$ and $2080 \mathrm{~s}$, respectively. For instance, Figure 3 shows the IDF curves of Tan Son Hoa for the past period (1978-2007) and for the 2050s period for A2 scenario (see also Tab. 1 for the computed extreme rainfall values).

\subsubsection{Rainfall intensity predictions at Dau Tieng, Loc Ninh and Can Dang stations}

Table 2 shows the increases of daily rainfall intensity (in percent, \%) predicted for Dau Tieng, Loc Ninh and Can Dang stations for different periods and under different scenarios. It is noted that the predicted increases become higher for later periods in the future for all these stations. In particular, for Dau Tieng station, the predicted increases are in a very good agreement with the predictions by the Vietnamese Ministry of Natural Resources and Environment (MONRE) based upon a different approach (MONRE, 2016). However, for Loc Ninh and Can Dang stations, the predicted increases in the present study are lower than those given by MONRE since the predictions by MONRE were based on the provincial (regional) scale that is much coarser than the point (rain gauge) scale used in this study.

\subsection{Flood flows and regulation}

Flood flows in the rainy season into the Dau Tieng Reservoir have been estimated by MARINE model. The basic input data for this model include: model parameters, initial conditions, topographical data (DEM, survey data), soil data, vegetation cover, meteorological data (rainfall, evaporation, humidity, etc.) and flow data for model calibration and validation. As indicated by Dinh et al. (2010), among different combinations of extreme daily rainfall data, the consecutive 3day model has produced the maximum flood discharge. Therefore, to calculate flood flows, the rainfall data for the consecutive 3-day period were used as shown in Table 3 for 1978-2017 and 2050s periods. Under the A2 scenario and for the 2050s, the maximum daily rainfall of Can Dang, Dau Tieng and Loc Ninh stations would be increased by 30,30 and $15 \%$, respectively.

The MARINE model has been calibrated for flood events with the available observed data from $26 / 9 / 1979$ to $15 / 10 /$ 1979. To evaluate the calibration results, common numerical performance indicators such as the root mean square error ( RMSE), NASH and Flood Peak Difference (FPD) were used. It 
Table 2. Comparison of the predictions of the rainfall intensity increases (\%) for different scenarios and periods for Dau Tieng, Loc Ninh, and Can Dang stations.

\begin{tabular}{|c|c|c|c|c|c|c|c|c|}
\hline \multirow[t]{2}{*}{ Study } & \multirow[t]{2}{*}{$\underline{\text { Scenarios }}$} & \multirow{2}{*}{$\frac{\text { Stations }}{\text { Years }}$} & \multicolumn{2}{|c|}{ Dau Tieng } & \multicolumn{2}{|c|}{ Loc Ninh } & \multicolumn{2}{|c|}{ Can Dang } \\
\hline & & & From & To & From & To & From & To \\
\hline \multirow{9}{*}{ This study } & \multirow{3}{*}{$\mathrm{A} 2$} & $2020 \mathrm{~s}$ & 19.0 & 21.1 & 2.7 & 4.8 & 12.1 & 14.7 \\
\hline & & $2050 \mathrm{~s}$ & 24.8 & 28.7 & 4.9 & 13.4 & 18.7 & 31.6 \\
\hline & & $2080 \mathrm{~s}$ & 33.9 & 35.6 & 26.9 & 27.6 & 32.4 & 57.1 \\
\hline & & $2020 \mathrm{~s}$ & \multicolumn{2}{|c|}{19.4} & \multicolumn{2}{|c|}{6.9} & \multicolumn{2}{|c|}{21.4} \\
\hline & B2 & $2050 \mathrm{~s}$ & \multicolumn{2}{|c|}{29.2} & \multicolumn{2}{|c|}{10.3} & \multicolumn{2}{|c|}{25.1} \\
\hline & & $2080 \mathrm{~s}$ & \multicolumn{2}{|c|}{33.0} & \multicolumn{2}{|c|}{25.4} & \multicolumn{2}{|c|}{43.6} \\
\hline & & $2020 \mathrm{~s}$ & \multicolumn{2}{|c|}{19.6} & \multicolumn{2}{|c|}{2.1} & \multicolumn{2}{|c|}{8.6} \\
\hline & A1B & $2050 \mathrm{~s}$ & \multicolumn{2}{|c|}{28.6} & \multicolumn{2}{|c|}{7.0} & \multicolumn{2}{|c|}{20.5} \\
\hline & & $2080 \mathrm{~s}$ & \multicolumn{2}{|c|}{32.7} & \multicolumn{2}{|c|}{14.4} & \multicolumn{2}{|c|}{26.0} \\
\hline MONRE & RCP4.5 & $2080 \mathrm{~s}$ & 30 & 40 & 20 & 50 & 30 & 40 \\
\hline
\end{tabular}

Table 3. The daily maximum rainfalls at Loc Ninh, Can Dang and Dau Tieng stations.

\begin{tabular}{|c|c|c|c|c|c|}
\hline \multirow[t]{2}{*}{ Period } & \multirow{2}{*}{$\begin{array}{l}\text { Stations } \\
\text { Loc Ninh }\end{array}$} & \multirow{2}{*}{$\begin{array}{l}\text { Total max rainfall } \\
\text { in } 3 \text { days }(\mathrm{mm}) \\
314.4\end{array}$} & \multicolumn{3}{|c|}{ Max daily rainfall for consecutive 3 days (mm) } \\
\hline & & & 24.5 & 267.3 & 22.6 \\
\hline \multirow{2}{*}{$(1978-2017)$} & Can Dang & 313.3 & 22.5 & 246.7 & 44.1 \\
\hline & Dau Tieng & 283.5 & 36.5 & 243.0 & 4.0 \\
\hline \multirow{3}{*}{$2050 \mathrm{~s}$} & Loc Ninh & 361.6 & 28.2 & 307.4 & 26.0 \\
\hline & Can Dang & 407.3 & 29.3 & 320.7 & 57.3 \\
\hline & Dau Tieng & 368.6 & 47.5 & 315.9 & 5.2 \\
\hline \multirow{3}{*}{$\begin{array}{l}2050 \mathrm{~s}+\text { increases } \\
40 \% \text { of rainfall }\end{array}$} & Loc Ninh & 502.6 & 39.2 & 427.3 & 36.1 \\
\hline & Can Dang & 566.1 & 40.7 & 445.8 & 79.7 \\
\hline & Dau Tieng & 512.3 & 66.0 & 439.1 & 7.2 \\
\hline
\end{tabular}

was found that the MARINE model was able to simulate very well the flood events as indicated by the small RMSE value of $12.1 \%$, the high NASH value of 0.88 and the small FPD of $2.3 \%$ as well as by the excellent agreement between observed and computed flood flows as shown in Figure 4.

It is noted that the Dau Tieng Reservoir watershed has not ever been affected by tropical depression so far. However, the risk of this event has been discussed between the reservoir operators and the HCM City government during the rainy season of 2013, when the Haiyan storm occurred. It was supposed that under tropical depression conditions the 3-day maximum precipitations at Can Dang, Dau Tieng and Loc Ninh stations could be increased about $40 \%$ (see Tab. 3). Figure 5 shows the peak discharge for Dau Tieng Reservoir could reach $3544 \mathrm{~m}^{3} \mathrm{~s}^{-1}$ under this prediction.

At the Dau Tieng Reservoir, flood flows have been regulated by an adopted operating procedure. Every year, by the end of rainy season, the reservoir water level should be maintained at the normal level $(Z=24.4 \mathrm{~m})$ in order to supply enough water to downstream users. This required normal level could result in a high risk of flooding when a flood occurs. At any time in the flood season, the maximum water level must be lower than the threshold limit of $Z=25.1 \mathrm{~m}$ (based on the drainage of excessed discharges via spillway (see Eq. (1)). Figure 6 shows the inflows to the reservoir and the released discharges (through spillway).

\subsection{Flooding simulation and uplift impacts of Dau Tieng dam}

\subsubsection{Model setup}

Telemac2D model has been applied to simulate flooding in the lower SGDNB. This model consists of: (a) downstream of Dau Tieng Reservoir and the Sai Gon River; (b) downstream of Tri An Reservoir and Dong Nai River; (c) Song Be River; (d) Vam Co Dong River; (e) Vam Co Tay River. Other rivers such as Soai Rap, Long Tau are also involved in the model (see Fig. 7). For the canal and channel system, about 12 big channels and more than 300 canals are included in the model.

Tidal flats, streets as well as floodplains are processed by the model using wet/dry zone techniques. The wet/dry state changes are possible thanks to using the special water gradient algorithm. Roads at high elevation have significant flood-prevention effects. They have been extracted with their elevation from the DEM of $5 \times 5 \mathrm{~m}$ resolution of HCM City. There are 12 main roads and about 20 other roads have been included in the model. They have been discretised by small-size elements arranged under line-type forms to divide flood-prone areas in different parcels. For more precision, the elevations of these roads are manually imported from DEM, and eventually from in situ measurements. 


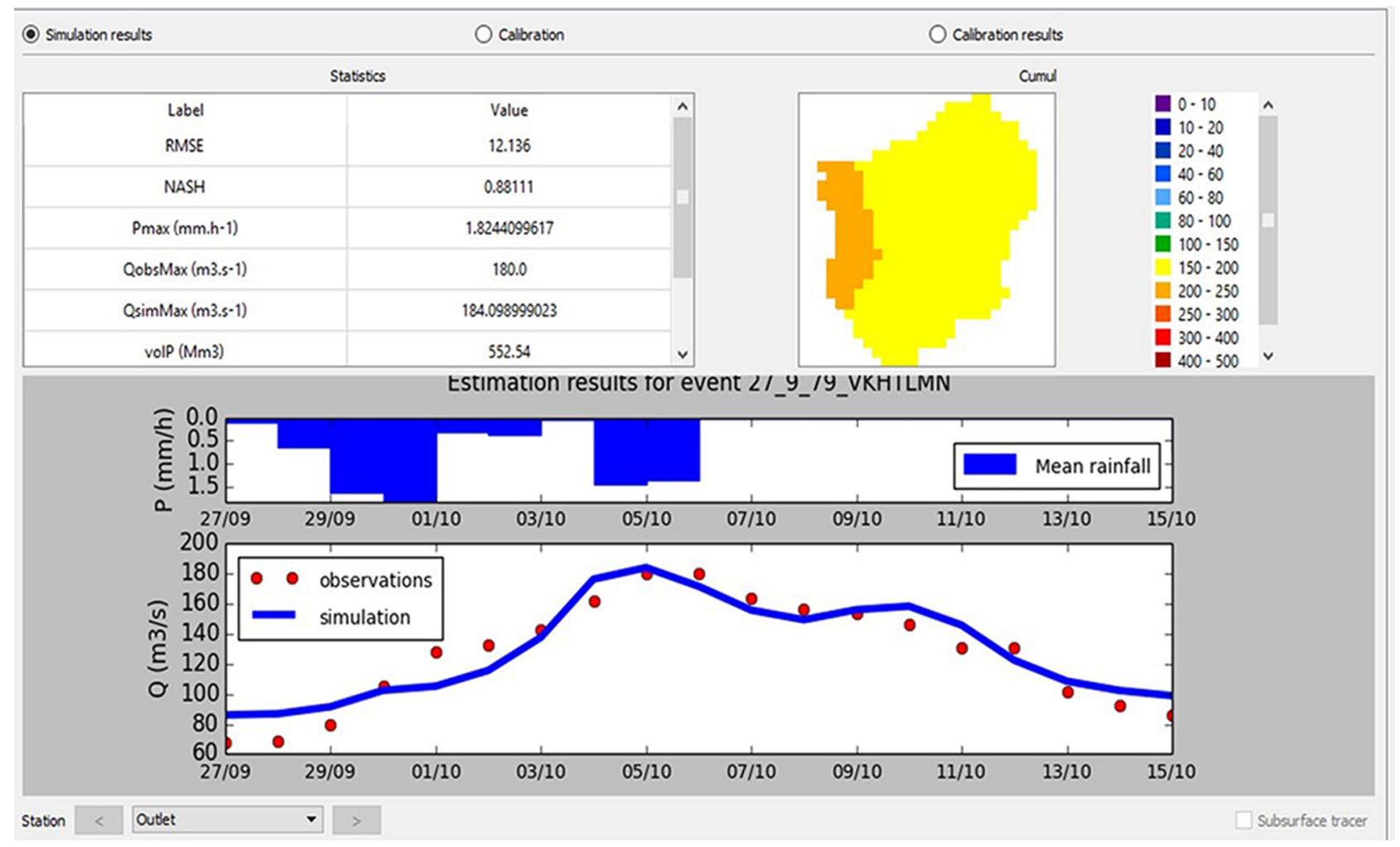

Fig. 4. MARINE model calibration result of flood flows - Period 26/9/1979 to 15/10/1979.

Urban topography is collected from DEM of Lower SGDNB, given in 2010 by MONRE at scale of 1/5000, 1/2000 for Tay Ninh, Long An, and Binh Duong provinces, and at scale of $1 / 25000$ for Dong Nai province. In addition, DEM $5 \times 5$ resolution of MONRE established in 2012 for HCM City, Long An and Tien Giang provinces are used. Moreover, cross-section data of channels and canals are selected from several past projects of SIWRR and other organizations.

Hydro-meteorological data used in calculations include: Water levels at Phu An, Nha Be, Thu Dau Mot, Tan An, Bien Hoa stations from 1978 to 2014 for calibration; The forecast tide level from the databases of FES2012, TPXO at Vung Tau station.

Discharge data: discharges from Dau Tieng and Tri An reservoirs since 1978 are used as discharge boundary. The short-term surveyed discharge data in 2006-2015 at some stations are used as calibration data.

Rainfalls at the lower SGDNB stations such as Bien Hoa, Binh Long, Can Dang, Dau Tieng, Go Dau, Loc Ninh, Long Thanh, Phuoc Hoa, So Sao, Tan An, Tan Son Hoa, Tay Ninh, Vung Tau from 1978 are used to compute the runoffs.

The computation mesh consists of 1248342 nodes and 2493430 elements (in the coordinates system UTM WGS $1984-48 \mathrm{~N})$ generated by BlueKenue meshing software. Elevation is referenced to Hon Dau national datum.

\subsubsection{Model calibration}

Three scenarios have been simulated for model calibration based on the flood events in the past (KB1, KB2 and KB3):
- KB1 scenario: Flood release combined with high tide: In November 2008, Dau Tieng Reservoir released approximately $600 \mathrm{~m}^{3} \mathrm{~s}^{-1}$ to downstream for a few hours, resulting inundation for the inner city and suburbs;

- KB2 scenario: Heavy rainfall combined with high tide: The rainfall on $21 / 7 / 2009$ that was very high $(82 \mathrm{~mm}$ from $13 \mathrm{~h} 30$ to $15 \mathrm{~h} 00$ ) associated with high tide caused severe flooding. The high-water level on the Sai Gon River resulted in dike breaking at 40 locations in HCM City, especially in An Phu Dong Ward, District 12 (22 points of overbank flows). Many places were inundated over $1 \mathrm{~m}$;

- KB3 scenario: High tide: For 3 days of high tides (7, 8 and 9 November 2010), the peak tide level measured at Phu An station was $1.56 \mathrm{~m}$ (the highest record in the last 50 years) caused severe flooding for 5 districts in the North of the city. Many sections of the dykes in Thu Duc and 12 districts had been broken.

The model calibrations were evaluated by Nash-Sutcliffe coefficient (R2). The different of peak tide levels (\%) also compared with the observed data. In addition, the observed flooded depths in some roads/streets were also compared. Moreover, the application of harmonic analysis of tidal wave component has been evaluated quantitatively. The model was calibrated for 3 scenarios with adequate results for management purposes. For instance, Tables 4 and 5 show the calibration results based on the comparisons between the observed and simulated data of peak-tide differences for KB1; flood depths for KB3, respectively. 


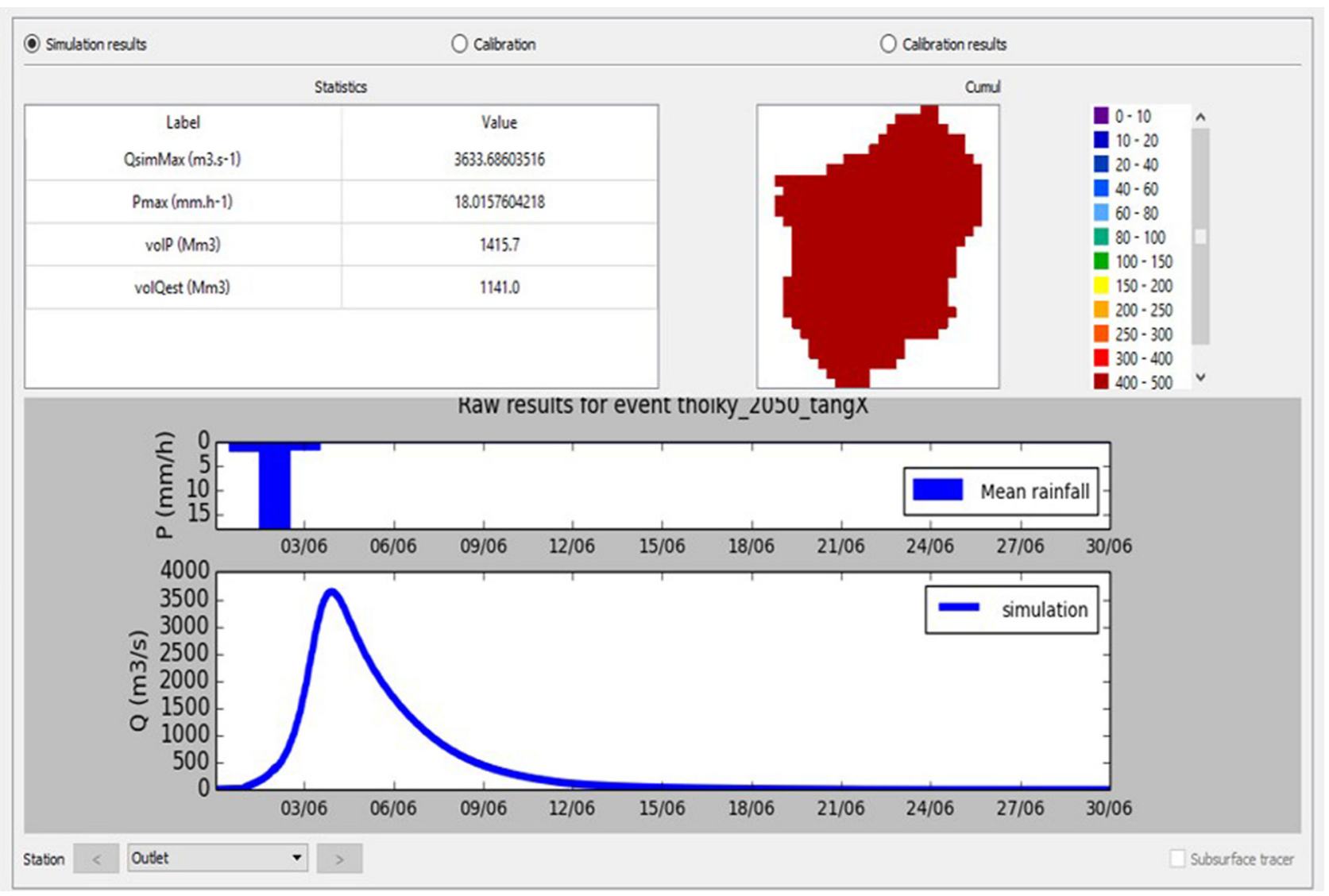

Fig. 5. Flood flow computation for Dau Tieng Reservoir (A2 scenario, period $2080+40 \%$ ).

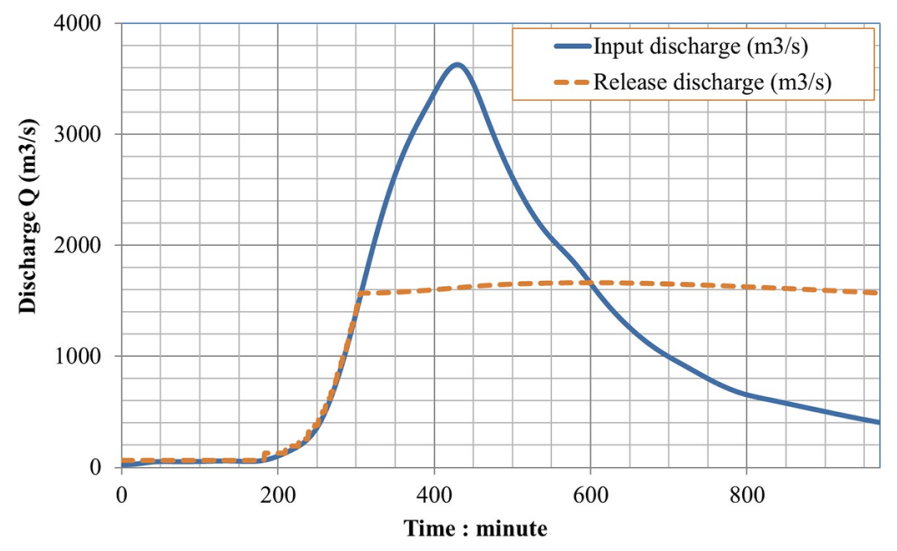

Fig. 6. The regulating flow for Dau Tieng Reservoir (A2 scenario, period $2050 \mathrm{~s}+40 \%$ ).

\subsubsection{Uplift impacts of Dau Tieng dam}

Based on the current operation procedure (Decision No.471/TTg dated 24/3/2016), in flood seasons, normally the Dau Tieng Reservoir is not allowed to release over $200 \mathrm{~m}^{3} /$ s. In the case of higher flood flows, and water levels are higher than the allowable highest level $(Z \geq 25.1 \mathrm{~m})$, flood releases must follow "the operation regulation for dam safety". It would be a big challenge to make an appropriate decision, if there is no solution based on possible scenarios that were simulated and planned beforehand. Therefore, this study tries to assess the uplift impacts of Dau Tieng dam on flood controls by comparison of downstream inundated areas according to the dam crest elevation. Three flood-discharge alternatives have been studied under the conditions of rainfall A2 scenario, by 2050s and increased to $40 \%$ due to tropical depression (see Tab. 3). The maximum release discharges via spillway are $1662 \mathrm{~m}^{3} \mathrm{~s}^{-1}$ (PA1), $500 \mathrm{~m}^{3} \mathrm{~s}^{-1}$ (PA2) and $300 \mathrm{~m}^{3} \mathrm{~s}^{-1}$ (PA3), when the downstream conditions are similar to scenario KB2 (heavy rainfall combined with high tide as on 21/7/2009). The reservoir water levels and the dam crests therefore increased by 1.0 and $1.5 \mathrm{~m}$ for PA 2 and PA3, respectively. The results on inundated areas at some typical areas in downstream compared to scenario KB2 are presented in Table 6 and Figure 8.

The analysis results in Table 6 show that with released discharges of 300,500 and $1662 \mathrm{~m}^{3} \mathrm{~s}^{-1}$, downstream inundated areas increase at 6989,7142 and 14286 ha, (equivalent to 3.4, 3.5 and $7 \%$ ) compared to scenario KB2, respectively. For typical areas in some districts adjacent to the Sai Gon River of the Tay Ninh and Binh Duong provinces, the inundated areas increase at 1650, 2754 and 5197 ha, equivalent to 48, 80 and $152 \%$ for PA3, PA 2 and PA 1 , respectively. This shows clearly that the most affected areas are just in the downstream part of the Dau Tieng Reservoir. At Cu Chi, Thu Duc, Hoc Mon (sub- 
C.S. Dinh et al.: La Houille Blanche 2019, Vol, 1-10

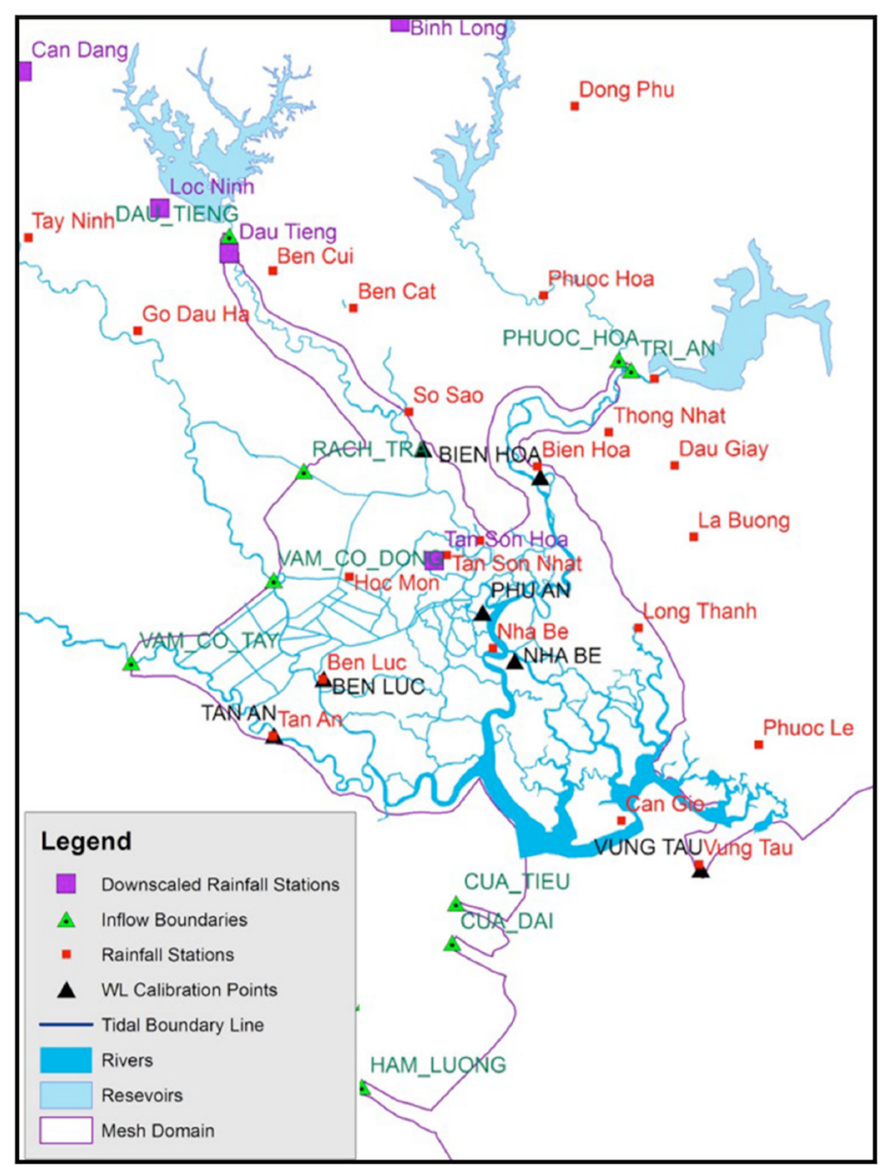

Fig. 7. Meteorological stations, calibration points and boundaries of Telemac2D model for lower SGDNB.
Table 4. Model calibration results of KB1 scenario-water level different.

\begin{tabular}{lcccc}
\hline Stations & $\begin{array}{c}\text { Calculated } \\
\text { Peak tide }\end{array}$ & $\begin{array}{c}\text { Observed } \\
\text { peak tide }\end{array}$ & $\begin{array}{l}\text { Peak } \\
\text { error (\%) }\end{array}$ & $\begin{array}{l}\text { Coefficient } \\
R^{2}\end{array}$ \\
\hline Ben Luc & 1.31 & 1.44 & 9 & 0.858 \\
Bien Hoa & 1.75 & 1.72 & 2 & 0.743 \\
Nha Be & 1.52 & 1.50 & 2 & 0.883 \\
Phu An & 1.45 & 1.52 & 1 & 0.908 \\
Thu Dau & 1.26 & 1.27 & 0.7 & 0.886 \\
Mot & & & & \\
Vung Tau & 1.36 & 1.36 & 0.1 & 0.991 \\
\hline
\end{tabular}

Table 5. Comparison of flood depth of scenario KB3.

\begin{tabular}{lcccc}
\hline Name of roads & $\begin{array}{l}\text { Observed } \\
\text { Inundation } \\
\text { depth }\end{array}$ & $\begin{array}{l}\text { Road } \\
\text { elevation } \\
(\mathrm{m})\end{array}$ & $\begin{array}{l}\text { Road } \\
\text { elevation } \\
(\mathrm{m}) \\
\text { on DEM }\end{array}$ & $\begin{array}{l}\text { Calculated } \\
\text { Inundation } \\
\text { depth }(\mathrm{m})\end{array}$ \\
\hline 3 Thang 2 & 0.20 & $4.76 ;$ & 2.8 & 0.20 \\
(From Cao Thang to & & $3.93 ;$ & & \\
$\begin{array}{l}\text { Su Van Hanh) } \\
\text { Xo Viet Nghe Tinh }\end{array}$ & 0.25 & $2.46 ;$ & 1.4 & 0.00 \\
& & 2.26 & & \\
Nguyen Huu Canh & 0.25 & 2.07 & 1.6 & 0.00 \\
3 Thang 2 & 0.15 & 2.61 & 2.8 & 0.20 \\
(Ton That Hiep) & & & & \\
$\begin{array}{l}\text { National route 1A } \\
\text { (at Le Thi Rieng) }\end{array}$ & 0.10 & $2.58 ;$ & 2.0 & 0.34 \\
& & $2.35 ;$ & & \\
\hline
\end{tabular}

Table 6. Comparison of inundation areas for various alternatives of flood release discharges.

\begin{tabular}{|c|c|c|c|c|}
\hline Inundated areas (ha) & PA1 & PA2 & PA3 & KB2 \\
\hline Release discharge $\left(\mathrm{m}^{3} \mathrm{~s}^{-1}\right)$ & 1662 & 500 & 300 & \\
\hline The whole areas downstream & 219329 & 212185 & 212032 & 205043 \\
\hline Increase compared to KB2 (ha) & 14286 & 7142 & 6989 & 0 \\
\hline Increase compared to KB2 (\%) & 6.97 & 3.48 & 3.41 & 0.00 \\
\hline Districts of $\mathrm{BD}$ and $\mathrm{TN}$ provinces & 8603 & 6160 & 5056 & 3406 \\
\hline Increase compared to KB2 (ha) & 5197 & 2754 & 1650 & 0 \\
\hline Increase compared to KB2 (\%) & 152.58 & 80.86 & 48.44 & 0.00 \\
\hline Districts Thu Duc, $\mathrm{Cu}$ Chi, Hoc Mon & 17589 & 15415 & 14998 & 14011 \\
\hline Increase compared to KB2 (ha) & 3578 & 1404 & 987 & 0 \\
\hline Increase compared to KB2 (\%) & 25.54 & 10.02 & 7.04 & 0.00 \\
\hline Districts 1 to district 12 & 16801 & 15718 & 15708 & 15518 \\
\hline Increase compared to KB2 (ha) & 1283 & 200 & 190 & 0 \\
\hline Increase compared to KB2 (\%) & 8.27 & 1.29 & 1.22 & 0.00 \\
\hline Long An province & 89892 & 89095 & 89025 & 87806 \\
\hline Increase compared to KB2 (ha) & 2086 & 1289 & 1219 & 0 \\
\hline Increase compared to KB2 (\%) & 2.38 & 1.47 & 1.39 & 0.00 \\
\hline
\end{tabular}




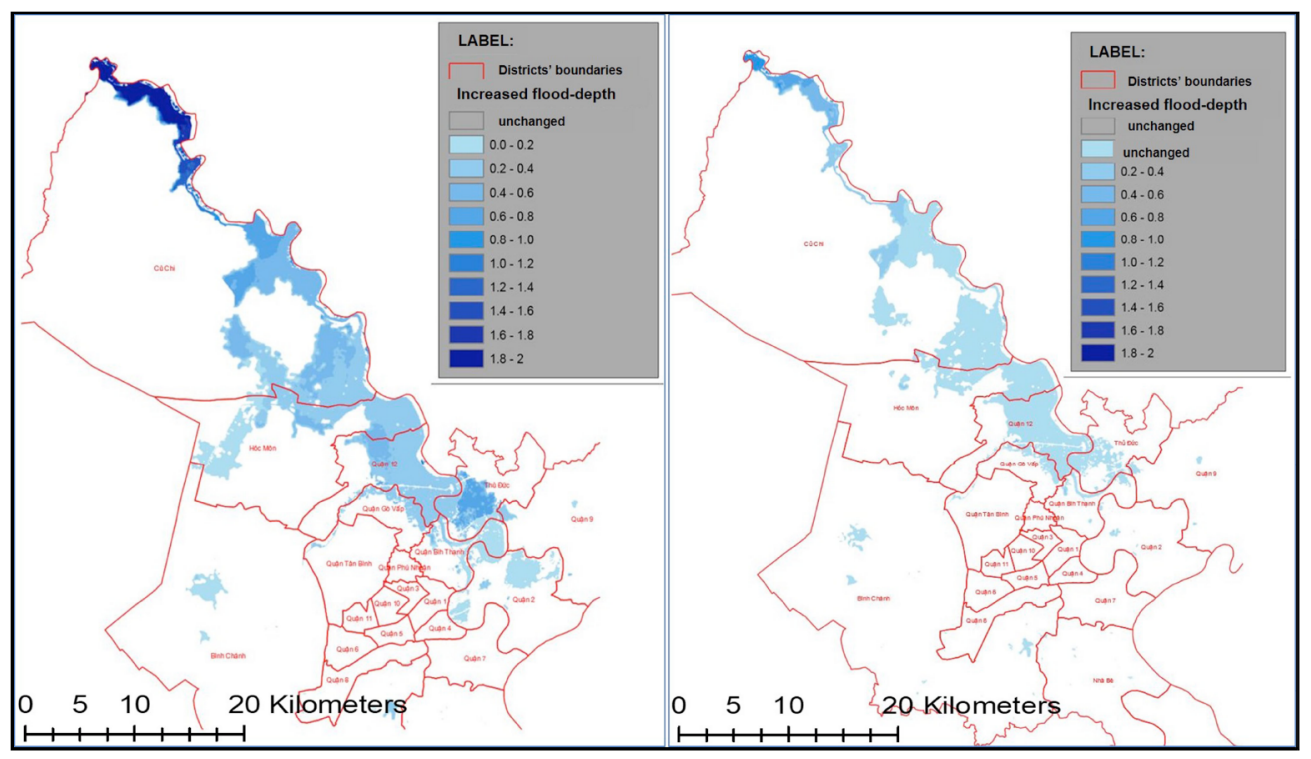

Fig. 8. The increase of inundated areas of PA1 and PA2 compared to KB2.

urban) districts, the inundated areas are only increased 987, 1404 and 3578 ha $(7,10$ and $25 \%)$. In the city-inner districts (1 to 12$)$, the increase rates are $1.22,1.29$ and 8.27 ha $(1.2,1.3$ and $8.3 \%$ ) for PA3, PA2 and PA1, respectively.

The Cost-Benefit Analysis (CBA) should be investigated further based on dam uplifting design and the application of flood damage functions for HCM City as by Huizinga et al. (2017).

\section{Conclusions}

An innovative approach has been proposed in this study for flood mitigation in HCM City in consideration of the potential impacts of Climate Change. The proposed approach was based on a combination of a Statistical Downscaling Model to assess the impacts of Climate Change on precipitations over the Dau Tieng Reservoir watershed and the lower Sai Gon-Dong Nai Basin area, MARINE (Model of Anticipation of Runoff and INundation for Extreme events) and Telemac2D models to simulate the flood flows from upstream of the reservoir and the inundated downstream area-particularly in HCM City.

More specifically, it was found that, due to the combined effect of potential Climate Change impacts on extreme rainfalls (by 2050s under the A2 scenario) and the possible increase of $40 \%$ due to tropical depression in the rainy season, the Dau Tieng Reservoir would be forced to release about $1660 \mathrm{~m}^{3} \mathrm{~s}^{-1}$. Consequently, the inundated areas of the Tay Ninh and Binh Duong Provinces, the suburb districts and the inner districts of HCM City could increase up to 150 , 25 and $8.3 \%$, respectively as compared to the KB2 scenario (heavy rainfall combined with high tide, the real flood event on 21/7/2009). Therefore, it is recommended that the Dau Tieng Dam should be uplifted to mitigate the downstream flooding, especially in HCM City. In addition, for the abovementioned Climate Change scenarios, further studies should be carried out to investigate the possibility of the Dau Tieng dam uplifting to 1.0 or to $1.5 \mathrm{~m}$ in order to consider the benefits generated from the reduction of inundated areas in the Tay Ninh and Binh Duong Provinces, in the $\mathrm{Cu}$ Chi, Thu Duc and Hoc Mon (sub-urban) districts and the inner-city districts 1 to 12 . On the other hands, with uplifting the Dau Tieng dam crest, besides of the advantage in flood controls, there should be other benefits such as water storage ability in the dry seasons to mitigate drought damages in order to cope with Climate Change for the lower SGDNB area. Furthermore, other solutions such as flood diversion or flood storage etc. should be considered in combination with the proposed solution in this study.

Acknowledgments. This study was funded by AFD for a "SFRM for the Sai Gon-Dong Nai River Basin" project and MOST for research project code KC08.07/16-20.

\section{References}

Cheng W-M, Huang C-L, Hsu N-S, Wei C-C. 2017. Risk analysis of reservoir operations considering short-term flood control and longterm water supply: A case study for the Da-Han Creek Basin in Taiwan. Water 2017 9(424): 1-23. DOI: 10.3390/w9060424 and Available from www.mdpi.com/journal/water.

Dinh CS, Le MH, Le TC, et al. 2010. Final report of National research project code KC08-16/06-10 "Research and building scientific foundations for management and sustainable development of the Dau Tieng-Phuoc Hoa water resources system to support socialeconomic development of the Southern Key Economic Zone" (in Vietnamese). Available from http://www.siwrr.org.vn/docs/2018/ files/San-KC08-16(06-10)-Publishing.pdf.

Estupina-Borrell V, Dartus D, Ababou R. 2006. Flash flood modeling with the MARINE hydrological distributed model. Hydrol Earth Syst Sci Discuss 3: 3397-3438. Available from www.hydrol-earthsyst-sci-discuss.net/3/3397/2006/. 
Hervouet J-M. 2006. Hydrodynamics of free surface flows. Modelling with the finite element method. The Atrium, Southern Gate, Chichester, West Sussex (England): John Wiley \& Sons Ltd, 390 p.

Huizinga J, De Moel H, Szewczyk W. 2017. Global flood depthdamage functions. Methodology and the database with guidelines. EUR 28552 EN. DOI: $10.2760 / 16510$.

MONRE. 2016. Climate change and sea level rise scenarios for Vietnam 2016 (in Vietnamese). Available from http://www.imh.ac. vn/files/doc/KichbanBDKH/TTkichban_2016.pdf.

Tingsanchali T. 2012. Urban flood disaster management. Procedia Eng 32: 25-37.
Verwey A, Kerblat Y, Chia B. 2017. Flood risk management at river basin scale: The need to adopt a proactive approach. Washington, DC: World Bank@ $\odot$. Available from https://openknowledge.world bank.org/handle/10986/27472 (License: CC BY 3.0 IGO).

Wilby RL, Dawson CW. 2007. SDSM 4.2-A decision support tool for the assessment of regional climate change impacts, version 4.2 user manual. Lancaster: Lancaster University, Lancaster/Environment Agency of England and Wales, pp. 1-94.

Wilby RL, Dawson CW, Barrow EM. 2002. SDSM-A decision support tool for the assessment of regional climate change impact. Environ Model Softw 17: 147-159.

Cite this article as: Dinh CS, Nguyen BD, Nguyen KD, Nguyen V-T-V. 2019. A possible solution for flood risk mitigation in Ho Chi Minh City and the lower Sai Gon-Dong Nai River Basin. La Houille Blanche Vol 